\title{
Globalization, Asymmetric War, and Increasing Number of International Refugees
}

\author{
Ayub Torry Satriyo Kusumo ${ }^{1 *}$, Jamal Wiwoho ${ }^{2}$, Emmy Latifah ${ }^{3}$ \\ ${ }^{2}$ Faculty of Law Universitas Sebelas Maret \\ Surakarta, Indonesia \\ ayub_kusumo@student.uns.ac.id
}

\begin{abstract}
Globalization has influenced all aspects of the human life, including the nature of armed conflict. İt is sensed that there is a shifting in armed conflict which resulted in inapplicability of International Humanitarian Law (IHL) in the conflict. The delay in IHL application bring collateral impact to the increase number of refugees, which coming to many countries in the world. This study analyze the shifting in armed conflict and its consequences in the case of international refugee which lead to a problem suffered by developing countries which has to welcome the incoming refugees. A study of regionalism become the basis of the idea in overcoming the refugee problem in developing countries, especially in South East Asia, in order to protect the refugee rights without sacrificing the country welfare.
\end{abstract}

Keywords- Armed conflict, International Humanitarian Law, Globalization, Refugees.

\section{INTRODUCTION}

Globalization is a process so that it can reach a very broad scope or can be applied widely. The area referred to in the definition is equivalent or intended to be equivalent to the whole world.[1] Bayliss argues that globalization is a process of increasing interconnectedness between various societies so that an event in one place may affect people and other communities in other places.[2] The process of globalization can occur as a result of the dynamics of inter-state activities or international organizations in the world. Globalization affects almost all aspects of the life, such as in the economic, political, scientific and technological, cultural, and social aspects.[3] Globalization has a multi-aspect concept with increasing economic, communication and cultural integration across national borders of the country [4] as if it blurs the limits (border) between nations and make the world community as being in a giant interconnected environment. On the one hand, globalization makes it easy and allows many things to happen such as free trade between countries, as well as communication and cooperation between countries in various fields. On the other hand, globalization also has negative impacts, such as trans-border crime, cybercrime, and even cross-border armed conflict.

Cross-border armed conflict is one of the consequences of globalization which shows the apparent blurring of national boundaries. At present, there has been a shift in the subject of armed conflict. In the past, armed conflicts occurred between countries, or between states and rebellion movements. At this time, the subject of the conflict is not country or belligerent. The current conflict happening across the state border or inside the border but violates the universal basis. An example of this case is the conflict between several countries in the Middle East against the radical movement known as Islamic State in Iraq and Syria (ISIS). According to authors, the conflict against ISIS has drawn into a new definition of international armed conflict compared to that of classic, which as well mentioned and regulated under the International Humanitarian Law (IHL) .

The International Humanitarian Law (IHL) is a basic and legal norms governing the protection of victims of armed conflict as defined in the Geneva Conventions of 1949. In its efforts to limit the damage and suffering as a consequence of armed conflict, IHL also considered customary international law and treaties international based on humanitarian goals. IHL protects those who not involved in the conflict, including hors de combat, and limit the ways and methods of conflict. IHL was specifically created to guarantee and protect the human rights of victims and non-combatants in an armed conflict.

Based on IHL, armed conflicts that have been regulated are classic types of armed conflicts. Armed conflict, as is the case today with ISIS for example, is a type of armed conflict that is not entirely the same as that governed by the IHL. In short, the authors are of the view that there has been a change or shift in the definition of armed conflict today in a more modern and globalized form. The author's view of the shift in the definition of international armed conflict is supported by Seibert who stated that the war on terrorism has put conflict in a different paradigm. Seibert thought that the war on terrorism is a new form of war, which is completely different from the classics in the identification section of involvement. In modern warfare, there is a clear involvement of private military companies and their economic interests. There are several points identified in modern armed conflicts such as the denial of military versus civil classification, dismantling of infrastructure, government and non-government cooperation, clear differences between conflicting parties, government chaos, and loss of boundaries between juridical and political interests. Often conflicts are based or accompanied by ethnic sentiment, racism, or fundamentalism.

One of the biggest impacts of an armed conflict is the victim, whether in the form of a human soul, natural wealth, cultural heritage and other cultural assets, as well as the political, economic and social stability of a country. 
With the spread of armed conflict that crosses national borders, the casualties are even greater. This situation results in a sense of insecurity for the residents who then move them to seek protection outside their country. In conditions like this, the population then becomes the asylum seeker can then change its status to refugees. In other words, this shift in armed conflict in the era of globalization has one consequence in the form of an increasing number of international refugees.

This writing aims to analyze the high number of international refugees as one of the consequences of globalization which brings armed conflict into a new form. This paper will open with an effort to define modern armed conflict in terms of its characteristics which are studied using the principles of IHL and the 1949 Geneva Conventions. The discussion continues with alternatives proposed by the author in the effort to enact IHL in order to protect human values so that excessive consequences can be avoided. As one of the consequences of the influence of globalization in the level of armed conflict, the authors describe the increasing wave of international refugees and the consequences of their participation in the countries of the world, one of which is Indonesia which is a developing country. The discussion of international refugee issues is analyzed using concepts and theories related to globalization and regionalism, especially in the Southeast Asian region. The problems to be answered through this article are what is the relationship between globalization and the shift in armed conflict in International Humanitarian Law, what are the consequences of shifting armed conflict to international refugees and what are the alternative solutions to the problem of international refugees, especially in developing countries.

\section{RESEARCH METHOD}

The study is a normative study on primary, secondary, and tertiary legal source. The primary legal source in this study is the 1949 Geneva Convention and its additional protocols, International Conventions on Refugees, multilateral or regional agreement on refugee matters as well as other international law sources related to refugees. The international regulation related to the international organization will also be the primary legal source. The secondary legal source will be relevant scholarly articles, expert commentary, and case studies on related subjects.

The study will analyze the definition of armed conflict based on International Humanitarian Law compared to the reality in armed conflict against ISIS or any practice towards or similar to it. The study will be followed by the practice of regionalism on refugee protection both in Asia and European Union as other example. The information will be collected and analyzed through analytical thinking and compared to the legal source available, both internationally, regionally, and nationally.

\section{FINDINGS AND DISCUSSION}

\section{The Relationship Between Globalization and the Shift in Armed Conflict in International Humanitarian Law}

International Humanitarian Law (IHL) applies to international armed conflicts as well as non-international armed conflicts. The enactment of IHL in international armed conflict is regulated in Article 2 of the 1949 Geneva Convention, as for the enactment of IHL in noninternational armed conflict is regulated in Article 3 of the 1949 Geneva Convention.

The regulation has the implication that there will be no longer any possibility for a country to circumvent the obligations of the convention by denying war in the legal sense, so that these conventions apply to every state in armed disputes even though the country is not a participant of the Convention.

According to IHL, a situation can be named as war if there are two elements, namely a conflict that uses armed force in one region and an intensity of the use of armed force which is quite high and organized. It can be concluded that war is a conflict between two parties in a certain region by using high-intensity armed force and terrorism from each party with the aim of subjecting the opposing parties and establishing peace requirements unilaterally. So that war can be identified as armed conflict. The IHL divides armed conflict into two, namely:

a) International armed conflict

International armed conflict is an armed conflict between - countries. Armed conflict between - the country consists of several circumstances as set out in Article 2 of common article 1949 Geneva Conventions as well as Article 1 (4) jo. Article 96 paragraph (3) 1977 Additional Protocol I. Article 1 (3) of 1977 Additional Protocol I states that the Protocol applies in situations referred to in Article 2 of the 1949 Geneva Convention. Article 2 of the 1949 Geneva Convention ruled the entry into force of the Convention in the case of:

(1) declared war;

(2) Armed dispute, even if the state of war is not recognized by either party;

(3) Occupation, even though the occupation encountered no resistance;

(4) For each country, even if the country is not a High Contracting Parties of the convention

Armed disputes as set out in Article 2 may occur between two or more High Contracting Parties or between the High Contracting Parties with no High Contracting Party, provided such party is a country. The term party also used at the time to explain about the armed conflict in which the state of war is not recognized. Whereas the situation of occupation in question is the occupation of an area carried out by the state. Thus, it can be said that the armed conflict as 
defined in Article 2 of the 1949 Geneva Conventions is a conflict that is happened between countries. Article 1 paragraph (4) of 1977 Additional Protocol I regulates additional definition of the situation referred to in situations as regulated in Article 2 of the Geneva Conventions namely armed conflict between a nation against colonial domination, a lien occupation and racist regime in order to exercise the right to self-determination.

b) Non- International Armed Conflict

Non-international armed conflict are conditions of battle between government and organized armed groups within the territory of a country. In this case the organized armed group had changed its status, from being originally a militia to being a belligerent. Article 13 paragraph (2) of 1949 Geneva Convention I regulates the qualifications of militias as belligerents, which is led by the person responsible for his subordinates, has a specific permanent identification that can be recognized from afar, carrying open arms, carrying out their operations in accordance with the laws and customs of war. The rules regarding the application of non-international armed conflict are stated in Article 3 of the 1949 Geneva Conventions and 1977 Additional Protocol. Article 3 of the Geneva Convention uses the term armed conflict not of an international character for each conflict that is not an international armed conflict. However, Article 3 does not provide a definition of what is meant by non-international armed conflict, so this gives rise to a very broad interpretation. Article 3 of the 1949 Geneva Convention requires each participating country to respect basic humanitarian rules in armed disputes that are not international in nature.

Therefore, Article 3 regulates the relationship between the government and its citizens, which means covering the traditional fields of human rights, so that there are minimum standards that must be met based on the principle of humanity. Although there is no juridical standard definition of non-international armed conflict, we can be guided by the commentary of the 1949 Geneva Convention. This commentary is a summary of the results of the trial and the opinions of experts which took place at the time of the formation of the Diplomatic Conference which resulted in the 1949 Geneva Conventions.[5]

Commentary on Article 3 of the Geneva Convention states that: "It was agreed by the Conference participants that the intention to formulate what is meant by "armed conflict" is canceled. Instead, it was agreed that there were proposals that contained the conditions that had to be fulfilled so that the Geneva Conventions could be applied in an armed conflict that was not international in nature. Although this proposal was not formally accepted (hence it was not formulated in a separate article in the
Geneva Conventions), it would be useful to predict under what circumstances the Geneva Convention would apply ".[5]

Based on the above provisions, a non-international armed conflict occurs between the de jure government of a country with an organized military force under its command against a belligerent group that is organized militarily and controls a part of the national territory. The war against ISIS is a dispute between the armed forces of a country or a joint state against armed groups in a country's territory. This raises the problem of including the war against ISIS in the category of non-international armed conflict because according to the authors ISIS cannot be categorized as a belligerent group or part of the de jure / state government. In other words, ISIS is not included in the parties to the dispute according to the four Geneva Conventions. In addition, there is no clarity on who the ISIS leader is and whether the leader is in command. There is also no clarity that ISIS has controlled certain areas permanently. It can be concluded that the war against terrorists is not a non- international armed conflict according to the four 1949 Geneva Conventions. While it is unfortunate that in the war against ISIS, both parties (the armed forces of a country or ISIS) often violate the provisions of the Convention such as causing many civilian casualties and damaging the objects protected in the Convention.

The unclear status of ISIS is almost similar to the discussion of the status of terrorists by Antonio Cassese when discussing terrorism related to $9 / 11$ in the United States. In his writings, Cassese mentioned that there was a debate about terrorist jurisdiction. Some countries such as Algeria, India and Sri Lanka believe that terrorists can be tried in the International Criminal Court (ICC) in the category of "crimes against humanity ". But some other countries, one of which is the United States, disagree with several reasons including the definition of terrorism and its unclear forms of attack, the tendency for political elements to be put on trial, some terrorist attacks whose impacts are not large enough to be tried internationally, and the opinion that national courts are far more effective in cracking down on terrorists. [6]

If it is reviewed deeply, the status of ISIS under international law not as state actor but as a non-state actor. In the war against ISIS, there were no declaration of war has made clear, though the Security Council of the United Nations (UNSC) has urged the international community to improve and expand attacks against ISIS.[7] The United States and its allies, including Arab countries, have carried out air strikes against ISIS militant groups in Syria.[8] ISIS also did not fight against colonial domination and foreign occupation, nor did it try to determine its own destiny by opposing racist governments. The authors believes based on an analysis of Article 1 paragraph (4) of the 1977 Additional Protocol I, the war against ISIS, although it involved many countries and the international community, did not necessarily make the war or conflict as an international armed conflict. This conclusion is drawn because ISIS is not a country or army that represents a country, nor is it 
belligerent, or not a country participating in the 1949 Geneva Conventions. Furthermore, who can become members of the Geneva Convention are a state, while the ISIS obviously is not a state. So that the status of ISIS in international law is a non- state actor. Based on the analysis above, the fight against ISIS cannot be categorized into both international armed conflicts and non-international armed conflict.

\section{Theory on Regionalism and Multilateralism.}

Globalization has brought relations between countries in the world to a new level, so as if these countries are members of a large community with unclear boundaries. Despite being in a large community with unclear boundaries, one thing that should not be forgotten in the study of globalization is the state sovereignty, because it is a fundamental principle in the study of international law. State sovereignty according to Jean Bodin, is being understood as the highest, absolute and eternal power, infinite, and cannot be divided. In this case, the definition applied to the sovereignty owned by the state in creating the law and regulate its citizens. According to the author, Bodin's opinion must be harmonized with the concept of sovereignty in international law in the era of globalization.

The discussion of sovereignty in International Law in the era of globalization cannot be separated from the nation state as a result of the 1648 Wesphalia Treaty.[9] Sovereignty here can be categorized into internal and external sovereignty. According to the author, Jean Bodin's Sovereignty Theory is a form of Internal Sovereignty that the sovereign state, has exclusive authority over certain areas without interference from foreign parties as in accordance with the principle of nonintervention. The external sovereignty places the state as an independent state and has the same degree to each other as stated by Grotius.

Grotius's teachings essentially emphasize the concept of two things: first, all humans actually have the same nature and second, therefore humans have a tendency to form a life together.[10] Besides having a tendency to live together, humans also want to live peacefully based on Sociality Awareness[11] which can be accepted by all nations so that it becomes the law of the nations. In living together with other countries, external sovereignty has a very important role. External sovereignty can be used by the state to regulate its foreign policy in dealing with other countries. Observing the current situation of globalization, countries will find it very difficult to overcome their own global dynamics and challenges by maintaining absolute independence, so the state will or will not have to follow the flow of global interdependence. Thus, to realize a balanced state life, internal and external sovereignty must run dynamically and harmoniously. As a form of harmonization between internal and external sovereignty, state law must be built from a fusion of interests that utilize external elements that are useful to him, as stated by Rudolf von Jhering.[11] So by referring to the three theories above, the true relationship between countries becomes a necessity in the current era of globalization. One form of relationship between countries can be in the form of regionalism as in the ASEAN community.

\section{Consequences shift Armed Conflict Against International Refugee in the Time of Globalization}

The shifting form of armed conflict in the international world has given its own problems in the application of IHL related to the subject of armed conflict. Another impact of the shift in armed conflict is the widespread suffering and casualties which then push the citizens of countries affected by armed conflict to get out of their country and seek protection. From here they have become asylum seekers and these asylum seekers will then become international refugees. Fear and insecurity encourage them to seek refuge in other countries that are more peaceful and more prosperous.

Today, the number of refugees are increasing is one result of the various conflicts in various parts of the world, most of which have changed or shifted its definition. This shift is one of the effects of globalization which seems to obscure national boundaries and make it a broad and interconnected society. With this shift in form of armed conflict, IHL cannot be immediately implemented and then requires a separate study as reviewed at the beginning of this paper.

As one of the consequences of the delay in the adoption of IHL on this shifting armed conflict, one of the impacts is the increasing number of international refugees. Of the many international refugees, some refugees have the goal of seeking asylum in European Union countries. The European Union is considered quite promising for the future of the lives of refugees. The large flow of refugees to European Union countries resulted in a crisis that we now know as the migrant crisis. This crisis then resulted in various policies, both the European Union's regional policies and the national policies of member countries, to cope with the large flow of migrants to EU countries. With the European Union's policies through special regulations such as Dublin Regulations, non-entrée policies through the national legal system, and physical development in the form of walls on land borders, the wave of refugees has changed to find alternative countries as a residence or asylum giver.

In terms of refugees, the existence of regional and national policies in limiting the entry of refugees is very detrimental. When viewed from the theory of human rights, refugees have basic rights that must be protected by anyone. People who try to seek protection and a safer life in another country initially become asylum seekers who then through a certain process get refugee status. Internationally, refugee protection is the responsibility of all countries. The international body responsible for managing refugees is the United Nations High Commissioner on Refugee (UNHCR).

The United Nations High Commissioner for Refugee (UNHCR) is the international body responsible for providing protection for refugees. One of its tasks is to determine the status of refugees, especially for countries 
that are not parties to the 1951 Convention or have not yet ratified the convention. For countries that have ratified the 1951 Convention or have their own national rules, they can provide refugee status. In practice, there is still a destination country that can refuse the entry of refugees through its national law, especially if the country is a developed country that is politically and economically strong in the face of the international community.

The possibility of violation of refugee rights does not only occur in developed countries that have prospered and are politically and economically established. Possible human rights violations also occur when refugees enter developing countries who are not sufficiently prepared to accommodate the refugees. Various resource limitations and bargaining positions that are less favorable for developing countries, coupled with adherence to the principle of non-refoulement, make developing countries inevitably accept the influx of refugees who are now increasing in number. An imbalance between resources and the number of refugees entering a country can be the start of an unintentional violation of refugee human rights, especially in developing countries.

\section{The problems of refugees arising in developing countries, including Indonesia}

Given the bargaining position of developed countries which often results in rejection or restrictions on the entry of international refugees, developing countries are usually considered "easier to enter" so that refugees choose to enter for the short term or even long term. Unfortunately, most of these countries have been burdened by their own domestic problems such as poverty, hunger, and infrastructure that has not yet been developed. The principle of non-refoulement can place developing countries with more problems for their own welfare. The risk of this burden is an unintentional violation of refugee rights due to the unpreparedness of the host country to protect refugees.[12]

A similar problem is faced by Indonesia, one of the developing countries in Southeast Asia. As one of the countries which has not yet ratified the 1951 Convention, Indonesia relies on UNHCR for the status of refugee determination. As long as the refugee status has not been determined, refugees still inhabit immigration detention and community shelters provided by the Indonesian government. With limited resources and funds, the government needs help. One of the international organization, the International Organization for Migration (IOM) provides assistance in managing refugee flows.[13] However, the increasing number of refugees appears to be faster than the resources provided. Limited resources can cause refugees to be negligent, receiving inappropriate treatment, suffering from uncertain long-term status, and many violations of refugee rights.

Some developing countries have realized that the burden will become greater over time while there is no comprehensive solution. Based on this awareness, several countries gather and agree to share the burden through cooperation, collaboration, regional or multilateral agreements. Sebastien wrote in his paper that there is a great need for regional collaboration.[12] There were some initial effort in managing the inflow of the international refugees for example the Manila Process, the Asia-Pacific Consultations on Refugees, Displaced Persons and Migrants, the Bali Process on People Smuggling, Trafficking in Persons and Related Transnational Crime; and the "Jakarta Declaration." The Association of South East Asian Nations (ASEAN) is also one of the regional organizations that has a great interest in the problem of refugees. However, these efforts are still limited to sharing information, discussing current issues, and are not yet a decisive policy or regulation. However, this can be considered as a starting point for building more comprehensive and stronger cooperation in overcoming the problem of refugees.[14]

\section{Analysis on Regionalism and Multilateralism Cooperation as Alternative Solutions for International Refugee Management in Developing Countries}

Regionalism and multilateralism in the Asia Pacific region today have many forms besides ASEAN which are the main pillars of regional cooperation. There is a push to expand cooperation between countries in the Asian region, particularly East Asia, to be more comprehensive without having to go through the mechanism of laying the foundation of the acquis communautaire (regulations and laws needed by the community) such as that of the European Union.

The definition of regionalism is the interaction or good relations of multiple aspects in a region. In addition, regionalism can also be interpreted as relations between states or interest groups that is well institutionalized in a region to achieve specific mutual aims from its members.

In the context of Southeast Asia, the discussion about regionalism cannot be separated from the Association of Southeast Asian Nations (ASEAN). ASEAN is undeniably made the process of regionalization of Southeast Asia take place more easily and quickly. One of the evident on regionalism cooperation has shown in the ASEAN Banking Integration Framework (ABIF) which shows the cooperation in the aspect of economic and financing.[15]

In the matter of managing refugee waves which coming into the country as an indirect consequence of globalization which has brought because of a shift in armed conflict in the world, developing countries will need to optimize their internal and external sovereignty to play an active part in international activities. It is obvious that the problem of international refugees has been faced by Indonesia, so an initial effort should be started by the government of Indonesia. This initial effort can be started to the surrounding environment or regional areas such as the Association of South East Asian Nations (ASEAN). As stated above theories, that inter-state cooperation is based on country's need to live together with the neighboring countries, build a strong Sociality Awareness, as well as a form of upholding external sovereignty. The regionalism cooperation can also become the means of Indonesia's active role in offering 
solutions to global problems, at least in the region of South East Asia.

An idea of sharing the burden among countries has been declared by the UN Secretary General in his report entitled "In Safety and Dignity: Addressing Large Movements of Refugees and Migrants". In his report, there was a term "responsibility sharing" or "sharedresponsibility" which then constructed into wider definitions and more operational act.[16] This idea of responsibility sharing has been discussed since 2017, however there still no exact or approved definition for it. There is still wide opportunity to construct it into more practical and operational terms in the future.[17] Given this opportunity, Indonesia which face problems on refugees also has a promising way on dealing with the refugees, especially by collaboration with neighboring countries.

\section{CONCLUSION}

With the shift in forms of armed conflict, the wave of refugees has increased and placed a burden on developing countries. Based on the analysis of regionalism and multilateralism, a cooperation in the form of multilateral agreement or a kind of action plan is needed for countries in the region to deal with refugee problems in this globalization era. The recommendation that the authors propose based on the theoretical study and discussion above is the need for the initiation of cooperation starting from the regional environment, for example in the form of bilateral or multilateral agreements in handling refugee problems. This initiation of cooperation is a concrete form of harmonization between theory and reality on the ground in an effort to resolve the issue of international refugees.

\section{REFERENCES}

[1] "Merriam-Webster Online Dictionary." https://www.merriamwebster.com/dictionary/globalization (accessed Apr. 12, 2020).

[2] J. Bayliss, The Globalization of World Politics : An Introduction to International Relation, 4th ed. New York: Oxford University Press, 2008.

[3] S. W. Gumbira and J. Wiwoho, "The Implication of Globalization on The Pancasila-Based Principles of Local Democracy in Indonesia," Padjadjaran J. Law, vol. 6, no. 2, p. 363, 2019.

[4] J. Rourke, International Politics on The World Stage, 10th ed. New York: McGraw-Hill Companies Inc., 2004.

[5] A. Permanasari, Pengantar Hukum Humaniter. Jakarta: ICRC, 1999.

[6] A. Cassese, "Terrorism is also disrupting some crucial legal categories of international law," Eur. J. Int. Law, vol. 12, no. 5, pp. 993-1001, 2001.

[7] V. Maulana, "DK PBB Desak Perkuat Serangan Terhadap ISIS." http://international.sindonews.com/read/912836/42/dk -pbb-desak-perkuat-serangan-terhadap-isis-
1413565200 (accessed Nov. 21, 2014).

[8] "AS dan sekutu Arab mulai gempur ISIS di Suriah." http://www.tempo.co/read/news/2014/09/23/11560908 7/AS-dan-Sekutu-Arab-Mulai-Gempur-ISIS-di-Syria, (accessed Nov. 21, 2014).

[9] Sefriani, Peran Hukum Internasional dalam Hubungan Internasional Kontemporer. Jakarta: Raja Grafindo Persada, 2015.

[10] A. Samekto, Pergeseran Pemikiran Hukum dari Era Yunani menuju Post-Modernisme. Jakarta: Konstitusi Press, 2015.

[11] B. L. Tanya, Y. N. Simanjuntak, and M. Y. Hage, Teori Hukum Strategi Tertib Manusia Lintas Ruang dan Generasi. Yogyakarta: Genta Publishing, 2010 .

[12] S. Moretti, "UNHCR and the migration regime complex in Asia-Pacific: Between responsibility shifting and responsibility sharing," New Issues Refug. Res. Pap., no. 283, 2016.

[13] S. Taylor and B. Rafferty-Brown, "Difficult journeys: Accessing refugee protection in Indonesia," Monash Univ. Law Rev., vol. 36, no. 3, pp. 138-161, 2011.

[14] E. Guild, C. Costello, M. Garlick, and V. Moreno-lax, "The 2015 Refugee Crisis in the European Union," no. 332, pp. 1-6, 2015.

[15] H. Wijaya, J. Wiwoho, and E. Latifah, "ASEAN Banking Integration and Its Impacts on the Banking Industry in Indonesia," Adv. Soc. Sci. Educ. Humanit. Res., vol. 358, 2019.

[16] V. Türk, "Prospects for Responsibility Sharing in the Refugee Context," J. Migr. Hum. Secur., vol. 4, no. 3, pp. 45-59, 2016, doi: $10.1177 / 233150241600400301$.

[17] K. Appleby, "Strengthening the Global Refugee Protection System: Recommendations for the Global Compact on Refugees," J. Migr. Hum. Secur., vol. 5, no. 4, pp. 780-799, 2017, doi: $10.1177 / 233150241700500404$. 